\title{
Identification and Chronology of Some Koguryŏ Royal Tombs
}

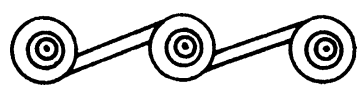

\author{
Mark E. BYington
}

\begin{abstract}
The Ji'an region on the middle reaches of the Yalu River served as the capital of the Koguryŏ kingdom during its middle period (ca. C.E. 200-427), as abundantly attested by archaeological remains in and around the town of Ji'an in the southernmost part of Jilin Province in northeastern China. Among these remains are a number of enormous mounded tombs made of stone or earth, many of which are believed to represent the burials of Koguryŏ kings, about a dozen of which should have been interred in this region. Since the beginning of the present century, Chinese archaeologists have engaged in intensive excavations and surveys on these tombs. The results of this work enable us to learn more about Koguryŏ's elite tombs, when they were constructed, and the possible identity of their occupants. This study focuses on a small subset of tombs that very probably represent those of Koguryŏ's kings. Architectural characteristics, relative locations, and artifactual contents (particularly roof tiles) are used to suggest how royal tombs are to be identified, outline a relative sequence of construction, and propose a schema for associating individual tombs with specific rulers. This analysis sheds light on various characteristics of Koguryŏ mortuary systems, construction techniques, aesthetic sensibilities, and royal authority, while providing an opportunity to address a number of important and problematic features of scholarship on Koguryŏ. KeYwORDs: Koguryŏ, mortuary systems, Ji'an, royal tombs, chronology.
\end{abstract}

\section{INTRODUCTION}

THE FIRST YEARS OF THE TWENTY-FIRST CENTURY WITNESSED a burst of archaeological activity focused on the numerous massive tombs scattered in the hills and plains of Ji'an 集安 on the north bank of the Yalu River in China's Jilin Province (Fig. 1). These tombs are the burials of the rulers and elite of the Koguryŏ kingdom. They governed from this place from at least the early third century until 427, when the capital was moved south to the vicinity of present-day Pyongyang on the Korean peninsula. ${ }^{1}$ The information yielded in the course of this archaeological work has allowed researchers to probe much more deeply into the material culture and history of Koguryŏ than had previously been possible, resolving a number of longstanding problems while introducing a host of new questions. The present study aims to illustrate the value of this new information through an analysis of the mortuary system employed by the Koguryŏ elite in the interment of their kings. After introducing the Ji' an plain and the 


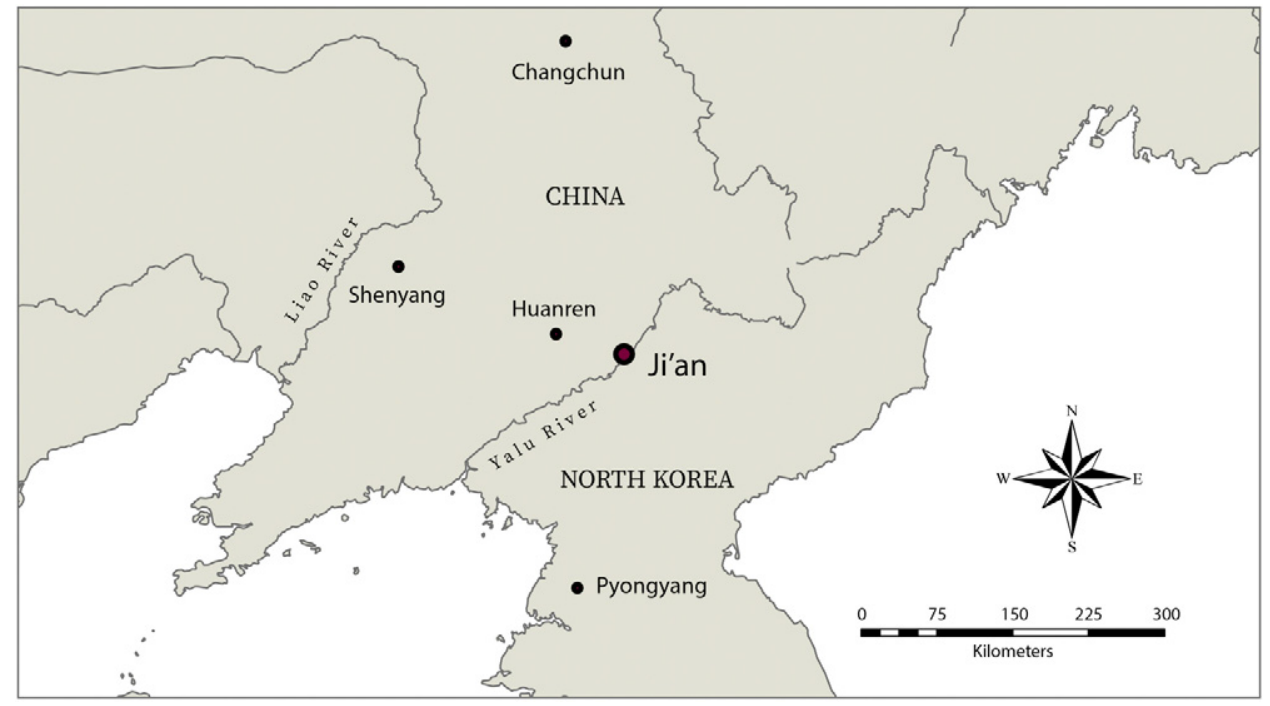

Fig. 1. Location of Ji'an.

large tombs that mark its landscape, I suggest various criteria for identifying royal burials and draw hypotheses on the associations between these tombs and specific kings named in historical sources.

The Koguryo kingdom formed in the first century B.C.E. and emerged as a centralized state by the early second century C.E. Its earliest political center is thought to have been in Huanren 桓仁 in the easternmost part of Liaoning Province, a region rich in early Koguryŏ remains, though archaeological data have thus far not provided conclusive evidence that this is in fact the site of Cholbon 卒本 (or Holbon 忽本), a place described in written records as the early capital of Koguryo. ${ }^{2}$ Around C.E. 200, a succession struggle resulted in the removal of the capital to the Ji' an plain, a strategically defensive area surrounded by mountainous terrain isolating and protecting it from surrounding peoples and polities (Byington 2004). ${ }^{3}$ According to various written sources, particularly the Samguk sagi 三國史記 (History of the Three Kingdoms, compiled in 1145), at least eleven kings came to power in the Ji' an region between ca. 200 and 427; these sources strongly indicate that at least nine of them would have been interred there (Kim 1991:152-172).

In addition to the many tombs in the Ji'an plain, which number at least 11,300 (Li 1980:166), there are two large walled sites, including the well-defended Wandu mountain fortress 丸都山城 to the north of the plain and the Guoneicheng 国内城 site in the plain to the south, from which the present town of Ji'an grew in the early twentieth century (Fig. 2). Extensive excavations were conducted at both of these walled sites in the early 2000s (Jilinsheng and Ji'anshi 2004b, 2004c). More wellknown is the King Kwanggaet'o stele to the east of the city (inscribed in 414); its inscriptions of nearly 1800 Chinese characters is a valuable historical source. Other remains, including tombs with wall murals, residential and temple sites, and a recently discovered inscribed stele in the western part of the plain, have all been subject to scholarly research. Since the early 2000s, focused archaeological activities were conducted in the Ji'an region in preparation for the inscription of these remains with 


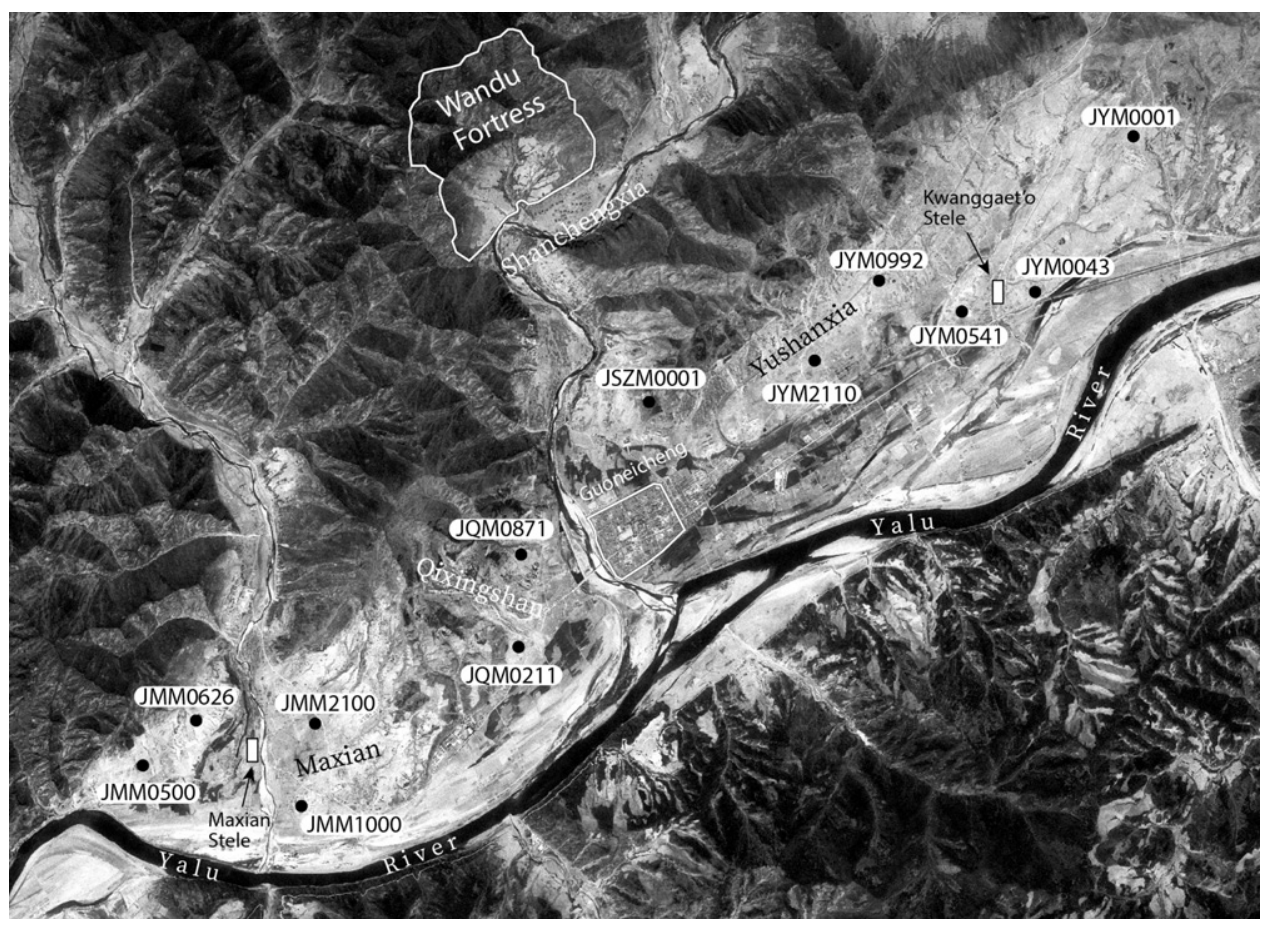

Fig. 2. Distribution of royal tombs in Ji'an (Base map May 1968 CORONA satellite image, held at National Archives and Records Administration).

UNESCO as World Heritage sites (approved July 2004). Research on the massive tombs was conducted primarily in 2003 under the direction of the Jilin Province Department of Culture 吉林省文化厅, with work conducted by numerous agencies, but primarily the Jilin Province Institute of Archaeology 吉林省文物考古研究所. The results of this work were published the following year in a volume edited by the Jilin Province Institute of Archaeology (Jilinsheng Wenwu Kaogu Yanjiusuo 吉林省 文物考古研究所) and the Ji'an City Museum (Ji'anshi Bowuguan 集安市博物馆) (Jilinsheng and Ji'anshi 2004a). Much of the analysis in this study is based on the data provided in this publication.

\section{IDENTIFYING ROYAL TOMBS}

Although much research has focused on the large tombs of Ji' an, there has been no consensus on how royal tombs (those of kings) are to be distinguished from other elite tombs or even if there is a clear observable distinction. The tombs in Ji' an are classified broadly into two general types based on their construction: earlier tombs are constructed of stone cairns and have either simple shaft pits or more complex stone chambers to house the human remains; later tombs are earthen mounds covering stone chambers. Both types appear in small, large, and massive scales. Some of the stone tombs once supported roofed structures, as evidenced by finds of roof tiles and tile ends scattered among the mounded stones. Although all of the large tombs appear to have been looted in antiquity, some have yielded small numbers of precious objects 

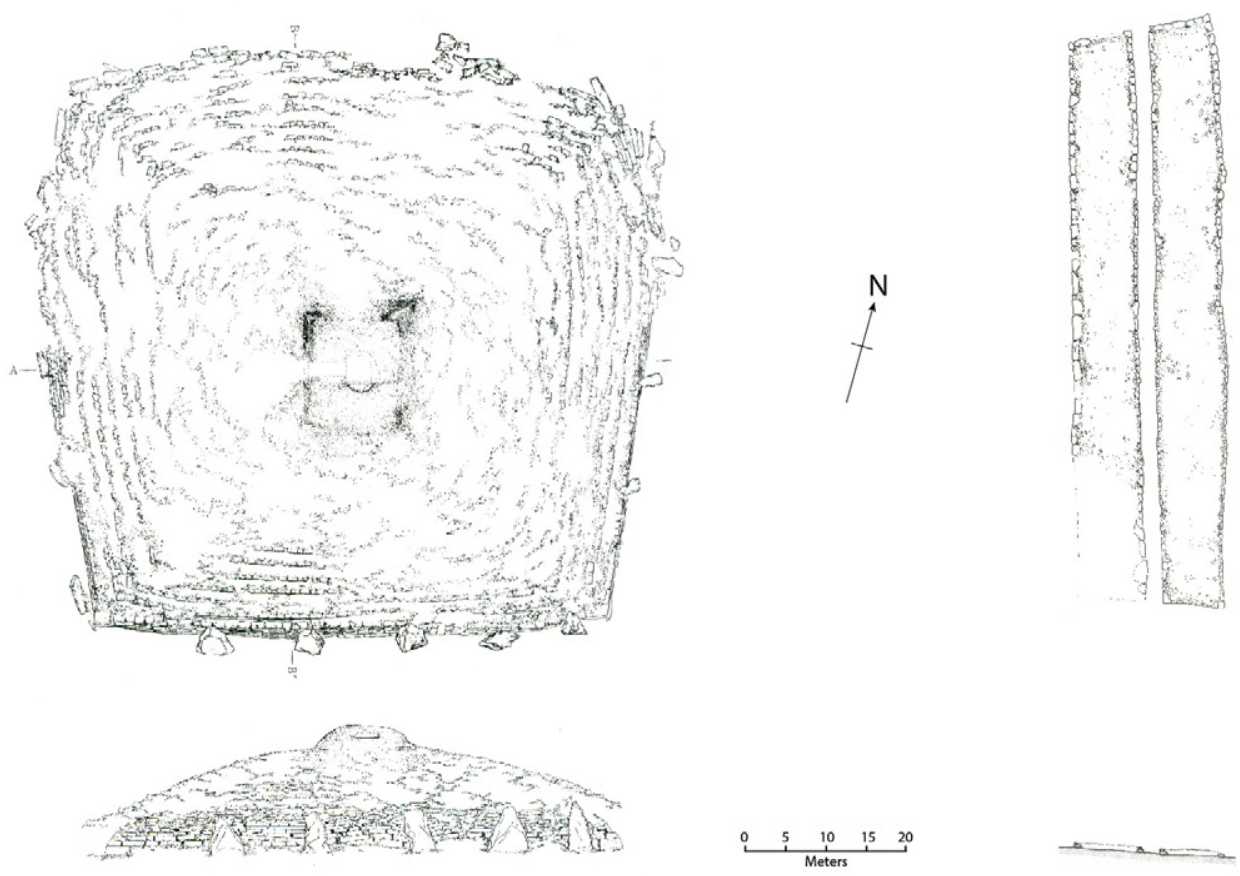

Fig. 3. Layout of the Tomb of the Great King: tomb (left); paired altar feature (right) (after Jilinsheng and Ji'anshi 2004a: figs. 179, 203).

suggesting the original richness of these burials. A very few of these tombs were so finely constructed or were built on such a scale that researchers have long accepted on this basis alone that they must have belonged to Koguryŏ kings. In modern times, such tombs have been given special descriptive names, such as Tomb of the General (Jiangjunfen 將軍墳), Tomb of the Great King (Taiwangling 太王陵), RiverViewing Tomb (Linjiangmu 臨江墓), Great Western Tomb (Xidamu 西大墓), and Tomb of a Thousand Autumns (Qianqiumu 千秋墓).

An illustrative example of such tombs is the Tomb of the Great King, more precisely designated JYM0541 using the taxonomy employed in China to identify archaeological features (Fig. 3). ${ }^{4}$ Located near the center of the large plain to the east of the town, this tomb dominates the vicinity. Nearly square in layout, each of its sides measures more than $60 \mathrm{~m}$ and it covers an area of over $4000 \mathrm{~m}^{2}$ (Jilinsheng and Ji' anshi 2004a:216-335). It is roughly pyramidal, consisting of at least ten stepped tiers topped by a stone cairn. The cairn covers a stone outer chamber, within which is a finely crafted stone inner chamber housing a pair of stone coffin platforms. Large numbers of roof tiles and tile ends have been found upon and beside the tomb, as have a few ceramic bricks, the sides of which feature a relief inscription reading "May the Great King's tomb be secure as a mountain and firm as a cliff” (願太王陵安如山固如岳) (Jilinsheng and Ji'anshi 2004a:317). These inscribed bricks gave the tomb its popular name and convinced scholars that it was indeed built for one of Koguryŏ's kings.

Surveys and excavations carried out in 2003 showed that the tomb sits in the center of a walled mortuary precinct with a gate to the south. The entrance of the tomb 
chamber opened to the west, while some $40 \mathrm{~m}$ to the east of the tomb was a pair of long stone platforms interpreted as ritual altars. A number of articles of gold, bronze, and iron missed by looters were found on or near the tomb, further suggesting a rich funerary tradition for Koguryŏ's highest elites. The treatment on Koguryŏ in the Sanguozhi 三國志 (Chronicles of the Three Kingdoms, compiled near the end of the third century) notes that "they have lavish funerals, and exhaust their gold and silver wealth and riches in sending off the dead” (厚葬，金銀財幣，盡於送死) (Chen 1992:844). The Tomb of the Great King may be viewed as an exemplar of Koguryŏ royal tombs of the late fourth and early fifth centuries. Its chronology and its proximity to the King Kwanggaet'o stele have caused many researchers to identify this tomb as that of Kwanggaet'o (r. 391-413), though some associate it with one of this king's predecessors. ${ }^{5}$

A number of criteria may be considered when assessing whether a given tomb represents a royal burial, including: size; number of tiers; existence of a walled precinct; use of roof tiles, tile ends, or bricks; type of burial chamber; presence of a ritual altar; or indications of rich burial goods. Considered too broadly, these criteria would suggest a number of elite tombs far greater than the total number of Koguryŏ kings. One feature, however, appears consistently among all of the tombs that clearly seem to belong to the highest elite figures: the "ritual altar" (jitan 祭坛). Although the function of this feature is not clear, it has been reasonably (and vaguely) interpreted as serving a ritual function associated with an assumed funerary ceremony, so in this study I will continue to refer to it as a ritual altar (Jilinsheng and Ji'anshi 2004a:376). Such altars are always placed to the east or northeast of the tomb itself, typically at a distance of 10 to $50 \mathrm{~m}$. ${ }^{6}$ They are usually formed of a platform of rocks in roughly rectangular layout, often four to five times as long as they are wide, and aligned lengthwise to run parallel to the northeast side of the tomb. There is usually a single altar for each tomb, though one tomb (JYM0541, Tomb of the Great King) has a pair of altar platforms placed side by side (Fig. 3), while another (JYM992) also appears to have two altars, but each is placed on opposite sides of the tomb. One massive tomb (JMM1000, Tomb of a Thousand Autumns) was noted to have had an altar feature in the 1930s (Fujita 1948:525), but its surface traces were not identified in the 2003 surveys. Aerial imagery from the 1950s, however, clearly shows this feature as a long, roughly rectangular platform measuring ca. $120 \mathrm{~m}$ x $30 \mathrm{~m}$. Later imagery shows that the feature was probably destroyed by building construction in the mid-1960s, which would account for its not appearing in the surveys of 2003.

I hypothesize that the ritual altar feature distinguishes royal tombs from other elite burials. The largest and most highly developed stone-piled tombs seem to have these features, including those that, based on independent criteria, are understood to be royal burials. Although the precise function of these features is unclear, they seem to be associated with either a one-time funerary rite or an ongoing ritual activity. Various factors suggest that deceased Koguryŏ kings were in fact the objects of ceremonial ritual. For example, there are references in the Samguk sagi to royal visits to a Progenitor's Shrine (始祖廟) (Kim 1991:315). More generally, the text of the Kwanggaet'o stele states that so-called "tomb households" were required to maintain the tombs and their associated precincts and perform regular sacrificial rituals (守墓酒 掃) (Han'guk 1992:16). The recently discovered Maxian stele similarly (and more explicitly) states that the tomb households were required to conduct regular sacrificial rituals (烟戶以此河流四時祭祀) (Ji'anshi 2013:44). Lastly, the fact that kings were 
Table i. List of Tombs in Ji'an with Ritual Altar Features

\begin{tabular}{lll}
\hline TOMB & \multicolumn{1}{c}{ POPULAR NAME } & NOTABLE FEATURES \\
\hline JMM626 & & \\
JQM871 & River-Viewing Tomb & \\
JYM0043 & & \\
JYM2110 & Great Western Tomb & Twin altars on opposite sides \\
JQM211 & & Area for altar covered by modern structures \\
JMM500 & & Altar noted in 1930s, not observed in 2003 \\
JYM992 & Tomb of a Thousand Autumns & Twin altars on east side \\
JMM2100 & Tomb of the Great King & \\
JMM1000 & Tomb of the General & \\
JYM0541 & & \\
JYM0001 & & \\
\hline
\end{tabular}

given posthumous names reflecting the location of their tombs may be an indication of a ritual function.

At least ten tombs in the Ji'an plain are known to have ritual altars. An additional tomb (JMM2100), which also seems to qualify as a royal tomb (see below), may have had an altar, but the area immediately to the northeast of the tomb is now covered by a public road and a residential area. These eleven tombs are listed in Table 1 (arranged in the chronological order I propose below). The tombs are distributed in what are today designated as three different tomb clusters. Five of them are in the large Yushanxia cluster 禹山下墓区, which stretches from north of the Guoneicheng walled site eastward to the foothills in the northeast. Two of them are in the Qixingshan cluster 七星山墓区 located in the mountains immediately to the southwest of Guoneicheng across the Tonggou River. Tombs in these two clusters would have been visible from the ancient walled site in the Ji'an plain. Four other tombs are located in the Maxian cluster 麻线墓区 in the valley of the Maxian River just over the Qixing Mountains to the southwest of the town. These tombs would not have been visible from the ancient walled town (see Fig. 2).

All eleven tombs in Table 1 are of the stepped tier variety, though of various levels of development, which may be attributed to chronological differentiation. All of them show clear evidence of having once supported a structure with roof tiles, some of them including tile ends, though several other tombs with roof tiles are not thought to belong to kings. The eleven tombs vary considerably in their dimensions (though all are among the largest in the Ji'an plain, ranging in base area from about 950 to nearly $5400 \mathrm{~m}^{2}$ ), and there is no linear correlation between base area and chronology. There have been several attempts to establish a relative chronology for the massive tombs in Ji' an based on various criteria, but these have been hampered by the lack of a single diagnostic index that applies to all of the tombs. The published 2004 report attempts to determine a relative sequence for the thirteen tombs it covers, but the chronological assignments it suggests are of dubious veracity, as they are based on the assumption that the Koguryo capital moved to Ji'an in 3 C.E. (Jilinsheng and Ji'anshi 2004a:369-372). Thus, those tombs judged to be early are dated to the first century, though there seems to be little support for this early date based on other criteria. 


\section{TILE ENDS AS AN INDEX FOR ESTABLISHING A SEQUENCE FOR LATER TOMBS}

Efforts to seek both a relative sequence of royal tombs and a basis for fixing some of them into an absolute chronology have been greatly assisted by the reports of the 2003 excavations. Even before this new information became available, clear indications of structural development have strongly suggested that the final three royal tombs built in Ji' an were, in chronological sequence, the Tomb of a Thousand Autumns (JMM1000), the Tomb of the Great King (JYM0541), and the Tomb of the General (JYM0001) (Wei 1994:60-62). This arrangement was made on the basis of the increasing complexity of architectural technique and sophistication, particularly with regard to the form of the burial chamber, and the inclusion of well-crafted roof tile ends featuring a lotus pattern. The Tomb of the General was in any case always judged to be the pinnacle of architectural sophistication for Koguryŏ stone-piled tombs, as it consisted entirely of carefully worked stone blocks in a seven-tiered pyramidal arrangement. The Tomb of the Great King suggests a highly developed construction technique with a pyramidal base of at least eight tiers topped by a piled stone cairn covering a well-designed burial chamber. The Tomb of a Thousand Autumns appears to be an immediate antecedent of the Tomb of the Great King, and though it lacks clear evidence of a stone burial chamber, large stone slabs on top of the tomb suggest the existence of a now-collapsed burial facility. Each of these three tombs featured lotus pattern tile ends, and they are the only three of the tombs considered here that have yielded such artifacts.

The study of tile ends is in fact very useful for establishing a relative sequence as well as a close absolute chronology for the last six of the eleven tombs in Table 1. One may argue that the use of roof tiles to establish a chronology of tombs is problematic because tiles could be placed on the tombs long after the burial mounds themselves were constructed. However, as will be seen below, the observed consistency of tile types among individual tombs and their clear stylistic development suggest that, with a very small number of possible exceptions, the tiles recovered from the mounds do indeed date to the initial construction of those tombs.

Before examining these tile ends, it is important to point out that while roof tiles were used in the construction of a number of elite tombs since at least the early third century (and possibly much earlier), the use of tile ends (wadang 瓦当), ornamental discs capping the lowermost row of cylindrical tiles (tongwa 筒瓦) on the eaves of a roof, did not appear in the structure of elite tombs until the fourth century. For the Koguryŏ tombs in Ji'an, there are two general types of tile ends (though a larger variety are found at nearby urban or palace sites). These tile ends are distinguished by their decorative patterns, the first called a curled-cloud variety (juanyun wen 卷雲紋), and the second a lotus pattern variety (lianhua wen 蓮花紋). Analyses of these tile ends have long shown clearly that the curled-cloud type immediately preceded the lotus pattern type (Wei 1994:97-100).

The curled-cloud tile ends have been found at four of the eleven tombs discussed here and are classified into two broad categories: an earlier type that features inscribed characters, and a slightly later one without characters. Those that are inscribed fortunately often include sexagenary date markers, allowing us to determine their exact year of manufacture. The tile ends are circular ceramic discs measuring roughly $14 \mathrm{~cm}$ to $16 \mathrm{~cm}$ in diameter. They feature a central raised circle, which may or may not contain inscribed characters, from which eight equidistant lines radiate, usually 
A

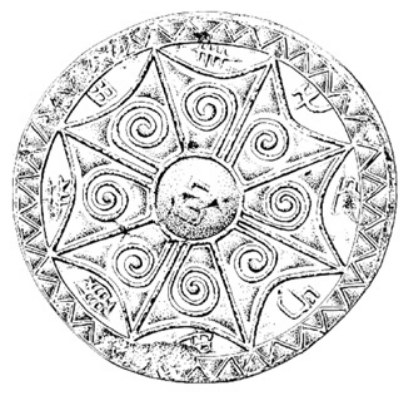

JMM500
B

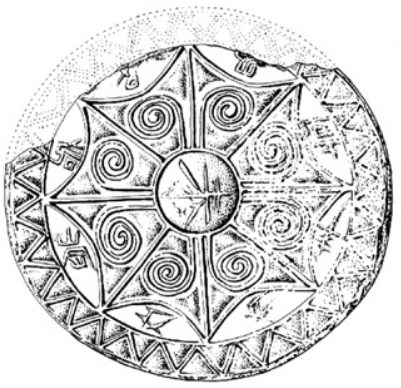

JYM992

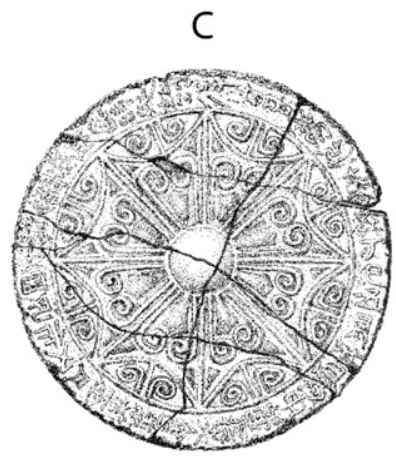

JYM3319

Fig. 4. Curled-cloud tile ends with inscriptions (after Jilinsheng and Ji'anshi 2004a: figs. 92, 106; Jilinsheng and Ji'anshi 2005: P1. 4).

terminating in an outer circular band, which features a sawtooth pattern. The ends of the radiating lines are connected to their neighbors by an inward curving line, creating eight lens-shaped areas which sometimes include characters. The spaces between the central core and the eight lens-shaped areas are each filled with a line extending from the core and curling into a tight spiral, resulting in alternating spirals that each mirrors its neighbors. This spiral has given this type of pattern its name.

The earliest royal tomb to yield curled-cloud tile ends is JMM500, popularly called the Great Western Tomb. Located at the western end of the Maxian cluster, this large tomb features a pyramidal base of worked stone blocks topped by a massive mound of river stones. The center of the tomb mound was completely dug out in antiquity, making its burial structure difficult to determine. The 2003 excavation yielded numerous roof tiles along with eleven end tiles, two of which were almost completely intact, while others were fragments (Jilinsheng and Ji'anshi 2004a:111-116). One well-preserved tile end was inscribed with eight characters, one in each of the lensshaped areas, yielding the inscription 已丑年 $\square \square$ 於利作 (the two missing characters are present but still undeciphered). The character $j i$ (K. ki) 己 was inscribed on the central core (Fig. 4, A). The inscription is interpreted to mean that the tile end was manufactured in the jichou (K. kich'uk) 已丑 year, which corresponds to 209, 269, 329, or 389. We will see below that of these dates 329 is by far the most likely, suggesting that tomb JMM500 was probably constructed in the years before and after 329, which falls in the later part of the reign of King Mich'ŏn (r. 300-331).

The only other tomb in this study that has yielded a similar inscribed tile end is JYM992, located near the center of the Yushanxia cluster. This tomb also features a pyramidal base of at least seven tiers topped by a cairn of river stones and rock (Jilinsheng and Ji'anshi 2004a:118-138). The 2003 excavation yielded 25 tile ends, all but one of which were of the inscribed curled-cloud type (the remaining one was a fragment of an unusual lotus pattern). The character tai (K. t'ae) 泰 is inscribed on the central core of these tile ends, and one relatively intact tile end contained the eightcharacter inscription 戊戌年造瓦故記歲 (Fig. 4, B). This indicates that the tile was manufactured in the $w u x u$ (K. musul) 戊戌 year, which corresponds to 218, 278, 338, 
or 398. Due to its stylistic similarity to the tile ends from JMM500 and for reasons discussed below, it is most likely that the tile end and the tomb itself were made in or around 338, which falls early in the reign of King Kogugwŏn (r. 331-371).

The selection of specific years for the sexagenary indicators inscribed on these tiles may be aided by comparison to those found at another tomb, JYM3319, which is not a royal tomb but is nevertheless elite and quite unusual. Located at the western end of the Yushanxia cluster, this tomb was excavated in 1997 and was found to be a brick chamber tomb covered by a Koguryŏ style stone cairn (JWKY and JB 2005). This tomb yielded a number of curled-cloud tile ends, some of which had been found as surface scatter years before. These tiles are stylistically very similar to those from JMM500 and JYM992, but each area between the radiating lines contains a pair of spiraled lines, while the lens-shaped areas contain smaller spirals rather than inscribed characters, which instead appear along the outer peripheral band in place of the sawtooth pattern. Based on several fragments, the entire inscription has been claimed to consist of 37 characters, reading 太歲在丁已五月廿日為中郎將大人造蓋墓瓦又 作民四千飤塱禾又用盈時輿詣得享萬世 (Fig. 4, C). This reading of the text, if correct, indicates that the tile was manufactured for the tomb in the dingsi (K. chóngsa) 丁巳 year for the burial of a person who was, based on his title and the inner construction of the tomb, very probably Chinese. ${ }^{7}$ The dingsi year corresponds to 297 or 357, of which 357 is almost certainly correct, as suggested by the recovery from the tomb of several pieces of Eastern Jin (317-420) celadon that have been compared to specimens from the Eastern Jin capital of Jiankang (modern Nanjing) (Jilinsheng and Ji'anshi 2005:23-24).

With the curled-cloud type of tile end reliably fixed to the mid-fourth century, we may confidently date the tile ends from JMM500 and JYM992 to 329 and 338 respectively. There are two other royal tombs that have yielded curled-cloud tile ends, but this variety lacks inscribed characters. Tomb JMM2100 lies in the eastern part of the Maxian cluster and is similar in structure to JMM500 and JYM992 but is smaller in scale (since the area to its east is covered by a road and a residential area, it is not known whether there was an altar feature, so it is possible it is not a royal tomb). JYM500 covers an area of $\sim 3200 \mathrm{~m}^{2}$, which is much larger than that for JYM992 $\left(\sim 1400 \mathrm{~m}^{2}\right)$ and JMM2100 $\left(\sim 1000 \mathrm{~m}^{2}\right)$. It yielded three curled-cloud tile ends very similar to those of JYM992, but instead of inscribed characters the lens-shaped areas feature a decorative scudding clouds pattern (Fig. 5, A). Although no inscribed dates were found associated with this tomb, an iron mirror and fragments of glazed pottery have suggested a date in the mid to late fourth century (Jilinsheng and Ji'anshi 2004a:167).

The fourth royal tomb to yield curled-cloud tile ends is JYM1000, popularly called the Tomb of a Thousand Autumns, located in the south-central part of the Maxian cluster about $750 \mathrm{~m}$ directly south of JMM2100. This massive tomb covers an area of well over $4000 \mathrm{~m}^{2}$ and consists of a large pyramidal base of at least ten tiers, with an upper cairn of river stones (Jilinsheng and Ji'anshi 2004a:168-216). The 2003 excavation recovered evidence that this tomb once had a stone inner burial chamber similar to that of the tomb of the Great King, and like that other tomb it featured bricks with sides inscribed with characters, this time in two varieties: "a thousand autumns, ten thousand years, forever firm” (千秋萬歲永固) and “protect firmly to the end of Heaven and Earth” (保固乾坤相畢), the former of which gave the tomb its popular name. This tomb yielded tile ends of both types. Most of the curled-cloud type were similar to those of JMM2100, but some lack the lens-shaped designs, while others 
A

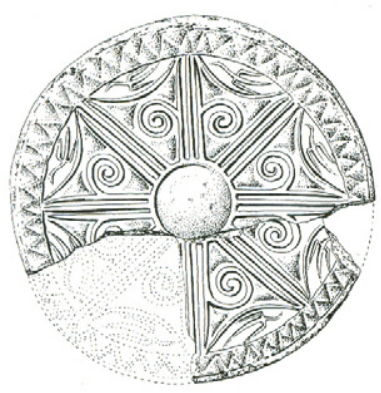

JYM2100
B

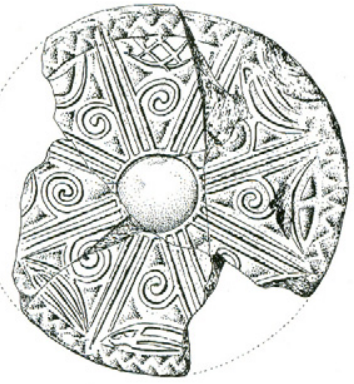

JMM1000
C

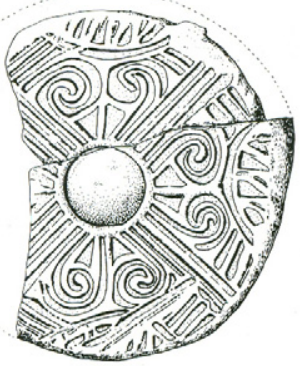

JMM1000

Fig. 5. Curled-cloud tile ends without inscriptions (after Jilinsheng and Ji'anshi 2004a: figs. 129, 167).

replace the scudding clouds with other designs (Fig. 5, B). There is additionally a variant type with the tile design divided into four sections rather than eight (Fig. 5, C). The vast majority of the more than 300 tile ends found at JMM1000, however, were of the lotus design variety, featuring double lines radiating from the core dividing the central band into six equal spaces, each occupied by a lotus petal (Fig. 6, A).

Tomb JMM1000 clearly represents a transitional phase for tile end design and appears to date to the late fourth century. Its structural similarity to JYM0541 (Tomb of the Great King) suggests that it immediately precedes that tomb in developmental sequence, which terminates in Ji'an with JYM0001 (Tomb of the General). The two latter tombs also feature lotus pattern tile ends, but in styles indicating stylistic development. The tiles from JYM0541 have patterns of six and eight petals in various types (Fig. 6, B), whereas those from JYM0001 have patterns of six, eight, and nine petals, again in a number of distinct variations (Fig. 6-C). Given this analysis of tile end design and late tomb development, we may postulate the following relative sequence of royal tombs:

JMM500 (329) $\rightarrow$ JYM992 (338) $\rightarrow$ JMM2100 $\rightarrow$ JMM1000 $\rightarrow$ JYM0541 $\rightarrow$ JYM0001.

A

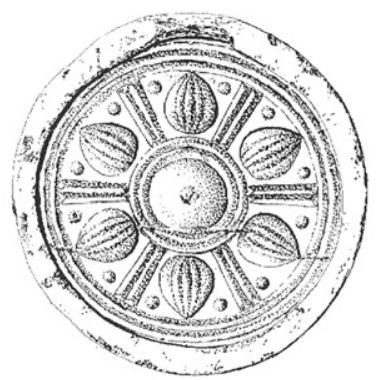

JMM1000
B

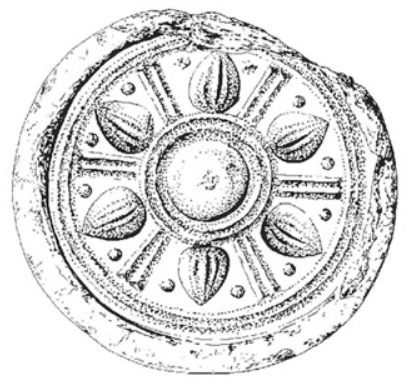

JYM0541
C

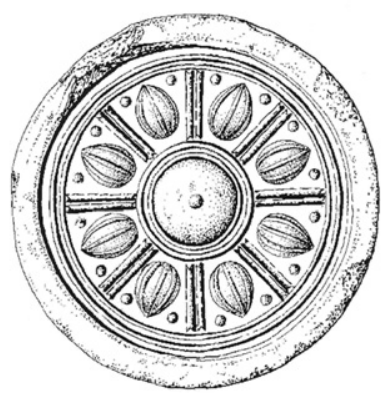

JYM0001

Fig. 6. Lotus pattern tile ends (after Jilinsheng and Ji'anshi 2004a: figs. 170-B, 236, 263). 
Table 2. Fourth Century Koguryŏ Kings and Their Burial Locations

\begin{tabular}{|c|c|c|c|c|}
\hline $\begin{array}{l}\text { POSTHUMOUS } \\
\text { NAME }\end{array}$ & $\begin{array}{l}\text { GIVEN } \\
\text { NAME }\end{array}$ & $\begin{array}{l}\text { REIGN YEARS } \\
\text { (C.E.) }\end{array}$ & $\begin{array}{c}\text { BURIAL } \\
\text { LOCATION }\end{array}$ & $\begin{array}{l}\text { ADDITIONAL DATA ON } \\
\text { BURIAL LOCATION }\end{array}$ \\
\hline Mich’ŭn & Ülbul & $300-331$ & Mich'ŏn Plain & \\
\hline Kogugwŏn & Sayu & $331-371$ & Kogugwŏn Plain & Also Kangsang or Kukkangsang \\
\hline Sosurim & Kubu & $371-384$ & Sosurim Forest & Possibly not in Ji'an \\
\hline Kogugyang & Iryŏn & $384-391$ & Kogugyang & \\
\hline Kwanggaet'o & Tamdŏk & $391-412$ & & Also Kukkangsang \\
\hline Changsu & Kŏryŏn & $412-492$ & & Probably buried in Pyongyang \\
\hline
\end{tabular}

We may also begin to draw some hypotheses regarding the occupants of these tombs. Table 2 shows the sequence of Koguryŏ kings during the fourth century.

Since the construction of a royal tomb in this period would have been a labor intensive event that would take years to complete, it is reasonable to assume that the kings would have had them built during their lifetimes. JMM500 (Great Western Tomb) should therefore be the tomb of King Mich'ŏn 美川王 (r. 300-331), constructed nearly three decades into his reign and shortly before his death. Mich'ŏn Plain, where he was buried, would have been the Maxian area. By similar reasoning, JYM992 should be the tomb of King Kogugwŏn, built less than a decade into his long reign. Since he is also referred to by the location of his tomb as Kangsang 岡上 or Kukkangsang 國岡上 (a location also later associated with the tomb of King Kwanggaet'o), this term must refer to the Yushanxia area. ${ }^{8}$ There are suggestions in the Samguk sagi that King Sosurim may have been buried outside of the capital region; if this is not the case, then tomb JMM2100 would seem to be the best candidate for his burial. His reign witnessed the introduction of Buddhism to Koguryŏ (traditionally said to have occurred in 372), and this may have been the motivation for the shift in tile end design to the lotus motif.

This transition is evident in JMM1000 (Tomb of a Thousand Autumns), which should be the tomb of King Kogugyang. The 2003 excavation yielded a roof tile fragment with a roughly incised inscription, a portion of which reads “ $\square$ 未在永樂,” which has been interpreted to indicate a year in the Yŏngnak 永樂 reign of Kwanggaet'o, with years ending in 未 including 395 (乙未) and 407 (丁未) (Jilinsheng and Ji'anshi 2004a:193). Since Kogugyang died only seven years into his reign, his tomb may not have been completed at the time of his death in 391 . The inscribed tile suggests that the construction was therefore completed during the reign of his successor.

The tomb of Kwanggaet'o must then be JYM0541 (Tomb of the Great King), an assignment long suspected due to the tomb's proximity to the King Kwanggaet'o stele. The reference to the location of the tomb as Kukkangsang reinforces the identification of the nearby JYM992 as that of Kogugwŏn (the two tombs stand only 900 m apart). Further evidence for this assignment appears in the report of the 2003 excavation, in which a bronze bell was recovered from the debris pile left by looters who broke into the burial chamber (Jilinsheng and Ji'anshi 2004a:270-272). This bell contained an inscription reading “辛卯年好太王 $\square$ 造鈴九十六,” indicating that the bell was made for the king in the xinmao (Kor. sinmyo) 辛卯 year, which corresponds to 391, the year of Kwanggaet'o's coronation according to the Kwanggaet'o stele. The bell is 
understood to have been among the king's personal effects interred with him and was perhaps a keepsake memorializing his coronation. The bell confirms both that the tomb belongs to Kwanggaet'o and that he came to power in 391. Note, however, that the titular term “好太王' (Good and Great King) appearing in the inscription need not have referred only to Kwanggaet'o, though it does appear in the long title of this king in the stele inscription. Further, the term seems to have been used in the lifetime of the king and does not constitute a strictly posthumous title.

Lastly, tomb JYM0001 (Tomb of the General) must have been built for King Changsu, but was likely never used because of the removal of the capital to Pyongyang in 427. Some scholars maintain that JYM0001 was used and was the tomb of Kwanggaet'o, but the data from the 2003 work makes this very unlikely. Unlike JYM0541, there were no traces of blocks or other materials that sealed the entrance of JYM0001 (though it is possible that such materials might have been carried away long ago). Further, other than a single gilt bronze ornament found to the south of the tomb, the 2003 excavations failed to turn up evidence of grave goods suggestive of a tomb that had been used (Jilinsheng and Ji'anshi 2004a:350-351). Although we cannot rule out the complete removal by looters of burial goods and entrance sealing blocks, their absence is suggestive of a tomb that had never been used (though it is quite possible that the attendant tombs located to the northeast of the primary tomb were in fact used).

USING TOMB STRUCTURE AND LOCATIONAL NAMES TO SEQUENCE EARLY TOMBS

Tile ends are especially helpful diagnostic artifacts in establishing a relative sequence of tombs, but they appear in tomb construction only at the beginning of the fourth century. We must seek other ways of determining the chronology for royal tombs prior to this time. For this we may turn to the architectural characteristics of tomb construction, occasional finds of burial goods, and the features of roofing tiles. We may also take advantage of the fact that from the end of the second century, the posthumous designations given to kings describe the location of their tombs. The five kings of the third century all have such designations: King Sansang 山上 (r. 197-227) was buried upon a mountain, presumably close to the capital; Kings Tongch'ŏn 東川 (r. 227-248), Chungch’ŏn 中川 (r. 248-270), and Sŏch’ŏn 西川 (r. 270-292) were buried in the eastern, central, and western areas of the capital region respectively. ${ }^{9}$ King Pongsang 烽上 (r. 292-300) was buried "in the plain of Pongsan (Beacon Mountain)." The accounts of these kings in the Koguryŏ Annals of the Samguk sagi provide some detail on the locations of the tombs. For example, the record for King Pongsang reads: “葬於烽山之原, 號曰烽上王 (He was buried on the plains of Beacon Mountain and was posthumously titled King Pongsang ['Upon the Beacon'])" (Kim 1991:162). The tombs of these kings are typically described as having been built on plains (原), suggesting an area that is relatively level or gentle in slope, though such areas might be located on the side or near the summit of a mountain. Such names suggest a ritual element in which the king is himself associated with his place of burial.

If we assume that the five tombs with ritual altar features remaining from our original list of eleven (i.e., the first five listed in Table 1) are indeed royal burials, they might be identified with the five third-century kings named above. The authors of the 2003 excavation report called attention to a distinction between two different methods of constructing the tiered pyramidal structures of the stone tombs of Ji'an (Jilinsheng 


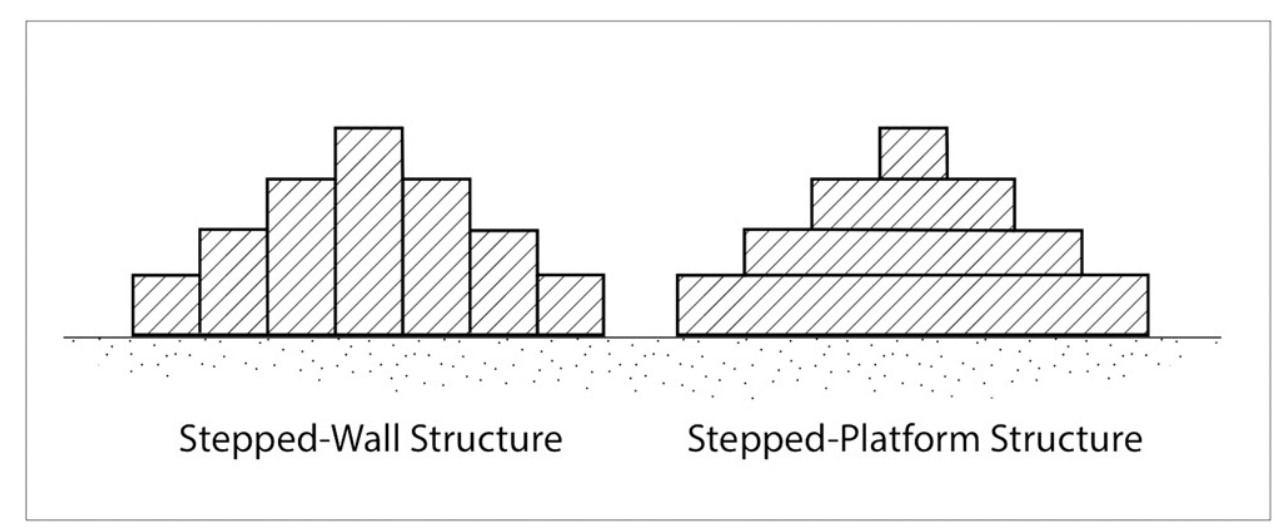

Fig. 7. Tomb cross-sections showing two structure types.

and Ji'anshi 2004a:373-375) (Fig. 7). The first and earlier is referred to as the steppedwall variety of stone-piled tomb (Ch. jieqiang jishi mu 阶墙积石墓), in which concentric walls are constructed from the ground up, the inner walls extending higher than the outer walls to create the pyramidal structure. The second, later type is called the stepped-platform variety (Ch. jietan jishi mu 阶坛积石墓), in which a base platform is completely built, upon which the next, smaller platform is completely constructed, and so on until the uppermost tier is completed. Of the eleven tombs considered here, all belong to the later stepped platform type except for two: JMM626 and JQM871; both of these are among the five tombs that do not feature tile ends and should therefore predate the fourth century. The other three tombs are JYM0043 (RiverViewing Tomb), JYM2110, and JQM211, which we may assume date to a period later than the first two.

Another index we may use to determine relative sequence is the surface features of roof tiles. In general, the earlier tiles tend to have a coarse cord-marked surface, whereas later ones have fine cord markings, and the latest variety have a smooth surface. This is not a completely reliable indicator of chronology, however, as some tombs yield tiles with both cord-marked and smooth surfaces, but the general trend in usage seems to be well attested. All five of the pre-fourth-century tombs used cordmarked roof tiles. Of the five tombs, JMM626 and JQM871 (both stepped-wall types) yielded coarse cord-marked tiles, giving additional support to their presumed earlier date of construction. JYM0043 and JYM2110 both yielded a variety of cord-marked and smooth surfaced tiles, while the majority of tiles from JQM211 were smooth, only a few being cord-marked. Another feature linking JYM0043 and JYM2110 is the fact that gilt bronze linchpins capped with human faces were found on or near the altar features of both tombs. The close similarity of these unusual linchpins suggests that the two tombs may be nearly contemporary.

An analysis of the tomb construction, roof tile surface qualities, and a limited comparison of artifact types suggests that JMM626 and JQM871 are relatively early, that JYM0043 and JYM2110 are later and nearly contemporary with each other, and that JQM211 is relatively late. From this basis we may turn to the posthumous titles of third-century kings for clues regarding the likely occupants of these tombs. The list of these kings appears in Table 3. 
ASIAN PERSPECTIVES • $2019 \cdot 58(\mathrm{I})$

Table 3. Third Century Koguryŏ Kings and Their Burial Locations

\begin{tabular}{|c|c|c|c|c|}
\hline POSTHUMOUS & GIVEN & REIGN & & \\
\hline NAME & NAME & YEARS (C.E.) & BURIAL LOCATION & NOTES ON BURIAL LOCATION \\
\hline Sansang & Yŏnu & $197-227$ & Mountaintop Tomb & \\
\hline Tongch'ŏn & Uwigǒ & $227-248$ & Brushwood Plain & (Eastern) Also Tongch’ŏn \\
\hline Chungch'ŏn & Yŏnbul & $248-270$ & Chungch'ŏn Plain & (Central) \\
\hline Sŏch’ŏn & Yangno & $270-292$ & Sŏch’ŏn Plain & (Western) Also Koguk Plain \\
\hline Pongsang & Sangbu & $292-300$ & Beacon Fire Mountain & \\
\hline
\end{tabular}

King Sansang was buried high on a mountain, a location best matched by JQM871, which overlooks the Guoneicheng walled site from a high prominence to the west. There is some logic to this placement, since it is the royal tomb closest to the population center in the Ji'an plain. Assuming that Sansang was the first king interred in this area, JQM871 would seem to be an ideal burial location. The next three kings were buried in the Ji' an plain in eastern, central, and western locations. It is likely that Tongch'orn and Chungch'on are the occupants of JYM0043 and JYM2110, respectively, due to their relative positions. Sŏch'ŏn's tomb would then be JQM211, which seems to be the latest of the five tombs. The relative chronology of these tombs thus makes for a clean match with the suggested locations of the first four kings of the sequence.

We are, however, missing an occupant for JMM626 and a candidate tomb for King Pongsang. JMM626 seems to be much too early to be the burial for Pongsang, and its crude cist-type burial pit suggests that it may predate JQM871 (which we have associated with Sansang). In fact, assuming that the other assignments proposed in this study are accurate, none of the tombs addressed in the report of the 2003 excavations is a candidate for the tomb of Pongsang. This king was assassinated in 300 in favor of his oppressed nephew (Mich'ŏn) and his body was interred on Beacon Mountain (Pongsan), presumably in close vicinity to the capital. Based on the various criteria presented here for identifying royal burials and placing them in a chronological sequence, the tomb of Pongsang should be a large-scale, stepped-platform type tomb with an altar feature, yielding evidence of roof tiles with fine cord markings or a smooth surface, and located high on a prominent peak.

Although it was not included in the 2004 report, there is one candidate that seems to meet all the criteria. A tomb designated JSZM0001 is located on a high elevation on the westernmost part of Yushan overlooking the town of Ji' an. ${ }^{10}$ A survey conducted in 2003 revealed it to be a stepped-platform tomb measuring $29 \times 35 \mathrm{~m}$ with a pair of large burial pits (Jilinsheng and Ji'anshi 2009). About $25 \mathrm{~m}$ to the east is a long rectangular feature of piled stones about $20 \times 8 \mathrm{~m}$ running parallel to the eastern wall of the tomb, which would seem to describe an altar feature. The survey recovered only a single cord-marked roof tile, which does not provide much useful information other than the fact that roof tiles were used in the tomb's construction. The tomb is located at the highest location of the cluster, on the southwestern face of the westernmost peak of Yushan, the top of which would have been a likely location for a signal fire beacon used for communicating between the walled town below and the mountain fortress to the north, as well as with the surrounding region. To date, however, no remains of such a beacon facility have been located to verify this supposition. Nevertheless, this tomb does appear to bear the characteristics of a royal burial, so it makes a good tentative candidate for the tomb of Pongsang. 
With regard to the occupant of JMM626, there are several possibilities. First, if I am wrong in suggesting that the Koguryŏ capital was not established in the Ji' an plain until about C.E. 200, JMM626 could be the tomb of an earlier king. I think this is highly improbable, however, for reasons I have described elsewhere (Byington 2004). It is also possible that my hypothesis that tombs with altar features are exclusive to kings is in error and that such features might have applied to other elites. If so, this tomb may have been the burial site of a local elite prior to the removal of the capital to Ji'an. Another possibility is that it is the burial of King Kogukch'ŏn 故國川, whose death in or about 197 prompted the succession struggle that resulted in the shift of the capital. Although he probably died and was buried in the former capital in the Huanren region, he might have been reinterred in Ji'an after the new capital was established. A fourth and more likely possibility is that JMM626 is the tomb of Palgi 發岐, the elder brother of Yŏnu 延優 (Sansang) who ultimately lost the succession struggle that resulted in the removal of the capital to Ji'an. Fragments of a Koguryŏ tradition claim that Palgi died and was buried in a place called Pae Stream 裴川, the location of which is unknown. Sansang later had him reinterred at (presumably nearby) Pae Pass 裴嶺 in a manner appropriate for a king. ${ }^{11}$ This was some three decades prior to the death of Sansang; the similarities between JMM626 and JQM871 suggest that they might well have been the burial sites for Palgi and Sansang, respectively. If so, it is notable that the burial of Palgi, while kingly in scale and ritual, is placed some distance away from the capital city itself, in a location that would not have been visible from the capital-perhaps a measure taken to prevent too obvious a reminder of the struggle that brought King Sansang to power.

\section{KOGURYǑ ROYAL TOMBS IN JI'AN}

Assuming that the chronology and tomb occupant assignments proposed here are accurate, the sequence and placement of royal tombs through time presents some interesting patterns (Fig. 2, Table 4). In the proposed scenario, the succession struggle at the end of the second century prompted one of the claimants, Younu, to remove the capital to the Ji'an plain, a place that was surely already a site of a significant Koguryo population. Yŏnu's unsuccessful brother, Palgi, died and was buried as a king in the vicinity of the new capital, but in an area removed from the new city and obstructed from view. This would have been the first royal burial in Ji'an, for which JMM626 is a good candidate. In 227, Yŏnu died and was buried on a high hill overlooking the capital city he built, and sometime later (possibly much later) he was given the posthumous name Sansang, which described the location of his tomb. JQM871 is an ideal match for this site.

With the new capital well secured and the kingdom prospering, the succeeding king Uwigo 憂位居 had his grand tomb constructed in the eastern plain of the capital, from which his posthumous name of Tongch'on was eventually derived. This is JYM0043, called the River-Viewing Tomb. It is likely that this tomb, which at $5396 \mathrm{~m}^{2}$ covers the largest area of all royal tombs in Ji'an, was built before the Wei invasions of Koguryo in the mid-240s, after which the kingdom went into a decline for some decades. This decline probably accounts for the relatively modest scale of JYM2110, thought to belong to King Chungch'ŏn, whose tomb would have been in the central part of the Ji'an plain. After Chungch'ŏn died in 270, he was succeeded by his son, whose posthumous name Sŏch’ŏn indicates a location in the western part of the plain. 
Table 4. List of Royal Tombs in Ji'an with Specifications and Possible Occupant

\begin{tabular}{|c|c|c|c|c|c|c|c|c|c|c|c|}
\hline \multirow[b]{2}{*}{ TOMB } & \multirow[b]{2}{*}{ ALT. NAME } & \multirow[b]{2}{*}{ ALTAR } & \multirow[b]{2}{*}{ CONSTRUCTION } & \multirow[b]{2}{*}{ BURIAL TYPE } & \multirow[b]{2}{*}{ TILE ENDS } & \multicolumn{4}{|c|}{ DIMENSIONS (M) } & \multirow[b]{2}{*}{ AREA $\left(M^{2}\right)$} & \multirow[b]{2}{*}{ OCCUPANT } \\
\hline & & & & & & $\bar{E}$ & $\mathrm{~s}$ & $\mathrm{~W}$ & $\mathrm{~N}$ & & \\
\hline JMM626 & & Yes & Wall & Cist & No & 41 & 48 & 42 & 42 & 1868 & Palgi (?) \\
\hline JQM871 & & Yes & Wall & Pit chamber & No & 48 & 46 & 40 & 46 & 2024 & Sansang 197-227 \\
\hline JYM0043 & Linjiangmu & Yes & Platform & Pit chamber & No & 71 & 76 & 71 & 76 & 5396 & Tongch'ŏn 227-248 \\
\hline JYM2110 & & Yes & Platform & Pit chamber Twin & No & 45 & 66.5 & 45 & 66.5 & 2993 & Chungch'ŏn 248-270 \\
\hline JQM0211 & & Yes & Platform & Pit chamber & No & 66 & 58 & $?$ & $?$ & $3828+$ & Sŏch’ŏn 270-292 \\
\hline JSZM0001 & & Yes (?) & Platform & Pit chamber Twin & No & 29 & 35 & 29 & 35 & 1015 & Pongsang (?) 292-300 \\
\hline JMM500 & Xidamu & Yes & Platform & Pit chamber & $\mathrm{CCh}$ & 53.5 & 62.5 & 56.7 & 53.5 & 3196 & Mich’ŏn 300-331 \\
\hline JYM992 & & Two & Platform & Pit chamber & $\mathrm{CCh}$ & 37.5 & 38.5 & 36.5 & 36.1 & 1380 & Kogugwŏn 331-371 \\
\hline JMM2100 & & Covered & Platform & Pit chamber & $\mathrm{CnC}$ & 33 & 29.6 & 32.2 & 33 & 1020 & Sosurim (?) 371-384 \\
\hline JMM1000 & Qianqiumu & Reported & Platform & Stone Chamber & $\mathrm{CnC}-\mathrm{L}$ & 67 & 60.5 & 62.6 & 71 & 4261 & Kogugyang 384-391 \\
\hline JYM0541 & Taiwangling & Yes & Platform & Stone Chamber & $\mathrm{L}$ & 62.5 & 63 & 66 & 68 & 4208 & Kwanggaet'o 391-412 \\
\hline JYM0001 & Jiangjunfen & Yes & Platform & Stone Chamber & $\mathrm{L}$ & 30.15 & 30.75 & 31.1 & 31.25 & 949 & Changsu 412-491 \\
\hline
\end{tabular}

Tile End types: $\mathrm{CCh}=$ Curled-Cloud with Characters; $\mathrm{CnC}=$ Curled-Cloud without Characters; L = Lotus Pattern. 
JQM211 is indeed located in the western plain. Its larger scale may indicate a gradual recovery following the devastating Wei invasions. Upon his death in 292, Sŏch'ŏn was succeeded by his son Sangbu 相夫, who was assassinated in 300 after a brief eight-year reign. Sangbu (Pongsang) was buried on a high peak near the capital, JSZM0001 being a likely candidate. Its relatively modest scale is perhaps reflective of both the insufficient time for the king to prepare his own tomb and the probable desire not to inter in too grand a manner a ruler who tradition has portrayed as extremely unpopular.

It is worth noting at this point that if my assignments are correct, the first five kings reigning in Ji'an were all buried in prominent locations in the Ji' an plain. Each of these tombs would have been directly visible from the capital city and each is placed a significant distance away from the others. This suggests a desire to assign each royal burial to an exclusive precinct while maintaining an orientation and placement through which each is tightly bound with the capital city itself.

With the rise of King Mich'ŏn in 300, Koguryŏ continued to develop and expand at a rapid pace. This king had his own tomb constructed nearly three decades into his reign, but he had it placed in the Maxian region near the presumed tomb of Palgi. The reasons for this are not clear. Perhaps Mich'ŏn associated himself with that region before he rose to power or perhaps the Ji' an plain itself was deemed to be already full up with royal tombs. In any case, JMM500 (Great Western Tomb) is surely the tomb of Mich'on and is the first to feature tile ends with curled-cloud patterns and dated inscriptions. After Mich'ŏn's death in 331, his son Sayu 斯由 commenced his long reign. In 342 the Murong Xianbei invaded the Koguryŏ capital and exhumed the body of Mich'on. The corpse was ransomed back the following year and presumably reinterred in its original tomb. ${ }^{12}$ The invasion was a severe blow to the kingdom, however, and it was some years before it recovered completely. Sayu evidently commenced the construction of his tomb by 338, based on the dates on tiles from JYM992; the fact that it was on a comparatively modest scale may suggest restraint in difficult times. Sayu died in 371 in a battle with Paekche; his posthumous title was Kogugwŏn, meaning "the plain in the capital." He was also called Kangsang or Kukkangsang, meaning "upon the capital plain," and it is worth noting that, unlike his father, he was buried in the Ji'an plain with the earlier kings.

Kogugwŏn was succeeded in 371 by his son Kubu 丘夫, whose thirteen-year reign witnessed the introduction of Buddhism to Koguryŏ. When he died in 384, he was buried in Sosurim 小獸林, or the Lesser Su Grove. This location and the fact that Kubu associated himself with an early (and possibly mythological) king who was buried in the Greater Su Grove 大獸林 may indicate that he was not interred in the Ji'an region. There is no strong evidence of this, however, and if Sosurim is in the Ji'an region, JMM2100 would seem to be a good candidate for this tomb on a stylistic basis. If this is correct, Kubu was buried on the opposite side of the Maxian valley from his grandfather Mich'oun. The relatively small scale of this tomb may suggest that its construction had not been completed prior to the king's death.

Sosurim had no sons, so he was succeeded by his brother Iryŏn 伊連, whose reign was even shorter at six and a half years. His posthumous name is Kogugyang 故國壤, which tells us only that it was in the capital region. Stylistic indications suggest that he was buried in JMM1000 (Tomb of a Thousand Autumns) and an inscribed roof tile indicates that the tomb was not completed until at least four years into the succeeding reign. The scale and grandeur of this tomb are suggestive of a secure kingdom and a 
powerful ruler. The shift in tile end design to a lotus pattern may indicate the new role of Buddhism in state power. Kogugyang was the last king buried in the Maxian plain. His son Tamdŏk 談德 became king in 391. He is best known for expanding the kingdom's territories through military might, a quality reflected in his posthumous name Kwanggaet'o 廣開土, meaning “broadly expanding territory." Although this title breaks with the convention of naming kings after their tomb locations, the Kwanggaet'o stele shows that he was also called Kukkangsang Hot'aewang 國岡上好 太王, meaning the "Good and Great King Upon the Capital Plain"; the locational portion of the name is shared with that of King Kogugwŏn. This is in turn reflected in the fact that the tomb of Kogugwŏn (JYM992) sits in close proximity to JYM0541 (Tomb of the Great King), thought on strong evidence to be the tomb of Kwanggaet'o.

Kwanggaet'o died in 413 and was succeeded by his son Kŏryŏn 巨連, who had one of the longest reigns in world history at 79 years. This longevity resulted in his posthumous name Changsu 長壽, meaning “long-lived." While the tombs of Kogugyang and Kwanggaet'o represent the developmental height of the tiered cairn style of tomb, the tomb of Changsu, JYM0001 (Tomb of the General), represents a step beyond that trajectory. It is a pyramid of worked stones and completely lacks the cairn structure. Although this tomb was evidently built for Changsu in the first decades of his reign, it seems never to have been used, since the Koguryŏ capital was removed to Pyongyang in 427 and a new tomb was presumably built for Changsu in the new capital. The most recognizable and highly developed of Koguryŏ's stone tombs was thus ultimately an empty monument left behind when the kingdom's attention was directed southward.

\section{CONCLUSIONS}

The archaeological data resulting from the 2003 excavations and surveys in Ji'an have added significantly to our knowledge of the history and material culture of Koguryŏ's middle period. The present study has explored the characteristics of royal tombs in Ji'an and has suggested ways of identifying them and establishing their places in a chronological sequence, finally drawing hypotheses on the probable occupants of each tomb. I have suggested that the ritual altar feature, the exact nature of which warrants deeper study, appears to be a reliable indicator of a royal burial and adds to our understanding of Koguryŏ elite funerary practice. To date we know of twelve tombs in Ji'an with altar features, which comes very close to matching the number of kings who should have been buried in this region, assuming the Koguryŏ capital was removed to Ji'an ca. C.E. 200. This does not, of course, prove my argument regarding the date of the capital transfer, since, for example, earlier royal tombs may not have employed this feature in their construction. However, the results of this study do strengthen my argument. Further, this study casts serious doubt upon the early chronology provided in the 2004 report, which was based on the unwarranted assumption that Ji'an served as the Koguryo capital from the early first century.

The use of tile ends as a diagnostic index for establishing a relative sequence of tombs in Ji'an is a longstanding practice, but the 2003 data provide some absolute dates allowing us to fix part of the sequence in time. The same chronology can be applied to non-royal tombs or other structures that also yield tile ends. For royal tombs predating the use of tile ends, structural differences and roof tile characteristics are helpful in 
estimating a general relative relationship, but in the case of the earlier royal tombs in Ji'an the posthumous naming convention applied to Koguryŏ kings allows a better basis for hypotheses as to the occupants of individual tombs. Future archaeological progress in Ji'an should either support the model presented here or call for its revision.

A number of useful observations can be made from the results of this study. The inscribed tile ends provide some rare absolute dates allowing us to fix certain tombs in a chronological sequence and they confirm that from at least the early fourth century kings usually had their own tombs constructed during their lifetimes. Further, the arrangement of royal tombs and their specific locations suggest an orderly progression in the placement of these tombs around the capital city. A significant characteristic of the placement of the first five tombs in the sequence is that they would all have been visible from the capital city. Three of the later tombs, beginning with that of Mich'on, were instead arrayed in the Maxian valley. Another observation that may be significant is the fact that the six royal tombs in the Ji' an plain (with the possible exception of that of Pongsang) would also have been visible from a low hill immediately to the north of the Kwanggaet'o stele, while those three or four royal tombs in the Maxian valley would have been visible from the assumed original location of the recently discovered Maxian stele. Whether there is any connection between the relative locations of the tombs and the stelae is a problem for future research.

As noted already, the proposed association of individual tombs with specific kings is hypothetical. Few of the associations are likely ever to be confirmed with irrefutable evidence, but the process of drawing such hypotheses reveals a number of interesting and useful observations, some of which have been addressed in this study. As might be expected, a deeper understanding of the nature of royal tombs in Ji'an produces a number of new problems and questions. Future excavations and surveys might uncover evidence of additional tombs with altar features, which would suggest that these structures hold a relationship to mortuary practice that is more complicated than suggested in this study. The discovery of Koguryŏ tombs with altar features outside of the Ji'an region would also be quite interesting, especially if they predate the third century. The chronological sequence and occupant associations outlined in this study could not have been proposed prior to the archaeological work accomplished in 2003. I hope that additional work in Ji'an and elsewhere will continue to deepen our understanding of the history and material culture of the Koguryŏ kingdom.

\section{NOTES}

1. The Koguryŏ kingdom held territories that covered areas that are today part of both China and Korea, so studies of Koguryŏ in English are typically forced to use a mixture of modern Chinese and Korean Romanization systems to account for modern contexts. Because Koguryŏ has been more closely associated historiographically with the Korean peninsula, this study uses modern Korean pronunciation to render Koguryŏ proper nouns, while the names of Koguryŏ archaeological sites in China are rendered in Chinese pronunciation. For example, the Koguryŏ capital city for the period we are treating is here given in Korean as Kungnae-sŏng, while the archaeological site associated with the walled capital city is given with its Chinese name of Guoneicheng. When context is more ambiguous, such as in the use of sexagenary cycle indicators, the practice here is to give the terms in Chinese with modern Korean following in parentheses.

2. The form Cholbon 卒本 appears in the Koguryŏ Annals (Koguryŏ pon'gi 高句麗本紀) of the Samguk sagi 三國史記 (History of the Three Kingdoms), a twelfth-century work of the Koryŏ kingdom compiled from earlier sources. The name of the early Koguryŏ capital appears as Holbon 忽本 in the text of the King Kwanggaet'o stele, which dates to 414. The two are generally understood to represent variants of the same name. 
3. I am in a minority in dating the shift from Huanren to Ji' an to ca. C.E. 200. Based on what I consider to be an uncritical reading of a passage in the Samguk sagi 三國史記, most scholars in East Asia date the shift to C.E.3. This fails to accord with other written sources (including other references in Samguk sagi) or with archaeological data. For further discussion, see No (1999), Byington (2004), and Yo (2005).

4. Tombs are typically numbered and prefixed with ' $\mathrm{M}$ ' for muzang 墓葬 or 'tomb'. A more complex system is used in Ji'an due to the large number of tombs there. These tombs are prefixed with ' $\mathrm{J}$ ' for Ji'an, followed by a letter indicating the specific cemetery or tomb cluster, followed by $\mathrm{M}$ for tomb. Since the Tomb of the Great King is part of the Yushanxia cluster, it is prefixed JYM. Maxian cluster tombs are prefixed JMM, Qixingshan cluster tombs JQM, and Shanchengxia cluster tombs JSM. These clusters collectively form the Donggou tomb cluster 洞沟古墓群.

5. In this study the names of Koguryo kings and their traditional reign years are based primarily on information preserved in the Koguryŏ Annals of the Samguk sagi, which is generally considered to be a reasonably reliable source for such data for the years considered here. The single exception is the reign of King Kwanggaet'o, in which case the text of the King Kwanggaet'o stele, which records the start and end of the king's reign a year earlier than the Samguk sagi, is considered a more reliable source.

6. Most Koguryo tombs and buildings in this plain tend to align with the flow of the Yalu River rather than with the cardinal directions. References to the eastern sides of tombs, for example, usually actually indicate a roughly northeastern direction.

7. It has been suggested that the tomb belongs to Cui Bi 崔毖, known to have fled to Koguryŏ in early 320. His flight is described in chapter 91 of the Zizhi tongjian (Sima 1992:2872-2874). For this interpretation and the reading of the tile inscription, see Zhang 2004. Although I do not believe that Zhang's reading is entirely reliable, the reading of the date is clearly correct.

8. His alternate name is given as 'Kukkangsang' in Samguk sagi (Kim Pusik 1991:164) and as 'Kangsang' in the chronological table of the thirteenth-century Samguk yusa (三國遺事, Memorabilia of the Three Kingdoms) (Iryŏn 1990:9).

9. For each of the kings with the character ch'ŏn 川 in their posthumous (tomb location) name, a variant account replaces this with the character yang 壤, which is perhaps an older term. Both should indicate an elevated plain.

10. The designation JSZM derives from its once having been considered part of the Shanchengxia cluster (hence the S), while the southern section to the east of the Tonggou River was in 1966 redesignated as the Zhuanchang 砖厂, or brickyard, cluster, after the brickyard operating in the vicinity (hence the Z, for zhuanchang). The tombs in this subdivided cluster are thus designated with the prefix JSZM.

11. Koguryǒ Annals, Sansang 1/9: “九月, 命有司奉迎發岐之喪, 以王禮葬於裴嶺” (Kim 1991:154).

12. Prior to the 2003 work, many scholars (myself included) have suggested that JMM500 was the tomb of Mich'on because the fact that it is completely dug out seemed to correspond to the desecration of the tomb of Mich'ŏn by the Murong Xianbei in 342, as attested in historical sources. However, the data yielded in 2003 suggests that, like the other royal tombs of this period (and completely unlike the much later tombs of Silla), the burial chamber would have been located at the top of the mound, making it unnecessary to excavate the entire mound to access the corpse interred therein. It is more likely that the current state of the tomb is owed to looters of many centuries later, who probably were disappointed when their efforts failed to yield burial goods.

\section{REFERENCES CITED}

Byington, Mark E.

2004 Problems concerning the first relocation of the Koguryŏ capital, in Han'guk Kodaesa Hakhoe 韓國古代史學會, ed., Koguryo ŭi youksa wa munhwa yusan 高句麗의 歷史와 文化遺産 [Koguryŏ's History and Cultural Heritage]. Seoul: Sŏgyŏng Munhwasa.

CHEN SHOU 陳壽

1992 Sanguozhi 三國志 [Chronicles of the Three Kingdoms], 5 vols. Beijing: Zhonghua Shuju.

FujiTA RYŌSAKU 藤田亮策

1948 Tsūkō fukin no kofun to Kōkuri bosei 通溝付近の古墳と高句麗の墓制 [Tombs in Tonggou and the Koguryŏ mortuary system], in Chōsen kōkogaku kenkyū 朝鮮考古學研究 [Studies of Korean Archaeology]: 497-540. Kyoto: Takagiri Shoin.

Han'guk Kodae Sahoe Yón'guso 韓國古代社會研究所 [Institute of AnCiEnt Korean Society] 1992 Han'guk kodae kŭmsóngmun 韓國古代史金石文 [Epigraphy of Ancient Korean History], vol. 1. Seoul: Han'guk Kodae Sahoe Yŏn'guso.

IRYŎN 一然

1990 Samguk yusa 三國遺事 [Memorabilia of the Three Kingdoms], ed. Yi Pyŏngdo 李丙壽. Seoul: Myŏngmundang. 
Ji’ANSHi BOWUGUAN 集安市博物馆 [JI’AN City Museum]

2013 Ji'an Gaogouli bei 集安高句丽碑 [The Ji'an Koguryŏ Stele]. Changchun: Jilin Daxue Chubanshe.

Jilinsheng Wenwu KaOgu Yanjiusuo 吉林省文物考古研究所 [Jilin Province Institute OF Archaeology] AND Ji’AnShi Bowuguan 集安市博物馆 [Ji'An City Museum]

2004a Ji'an Gaogouli wangling 集安高句丽王陵 [Koguryŏ Royal Tombs in Ji'an]. Beijing: Wenwu Chubanshe.

2004b Guoneicheng - 2000-2003 nian Ji'an Guoneicheng yu Minzhu yizhi shijue baogao 国内城 2000-2003 年集安国内城与民主遗址试掘报告 [Guoneicheng: Report on the 2000-2003 Test Excavations at the Guoneicheng and Minzhu Sites in Ji'an]. Beijing: Wenwu Chubanshe.

2004c Wandu shancheng - 2001-2003 nian Ji'an Wandu shancheng diaocha shijue baogao 丸都山城 2001-2003 年集安丸都山城调查试掘报告 [Wandu Mountain Fortress: Report of the 2001-2003 Survey and Test Excavation of Wandu Mountain Fortress in Ji'an]. Beijing: Wenwu Chubanshe.

2005 Donggou gumuqun Yushan muqu JYM3319 hao mu fajue baogao 洞沟古墓群禹山墓区 JYM3319 号墓发掘报告 [Excavation report of Tomb JYM3319 of the Donggou tomb cluster]. Dongbei shidi 东北史地 6:19-31.

2009 Ji'an JSZM0001 hao mu qingli baogao 集安 JSZM0001 号墓清理报告 [Report of the survey of Tomb JSZM0001 in Ji'an], in Jilin Ji'an Gaogouli muzang baogaoji 吉林集安高句丽墓葬报 告集 [Reports on Koguryŏ Tombs in Ji'an]: 277-284, ed. Jilinsheng Wenwu Kaogu Yanjiusuo. Beijing: Kexue Chubanshe.

KIM PUSIK 金富軾

1991 Samguk sagi 三國史記 [History of the Three Kingdoms], 2 vols., ed. Yi Pyŏngdo 李丙壽. Seoul: Ŭryu Munhwasa.

LI DIANFU 李殿福

1980 Ji'an Gaogouli mu yanjiu 集安高句丽墓研究 [A study of Koguryŏ tombs in Ji'an]. Kaogu xuebao 考古学报 2:163-184.

NO T’AEDON 노태돈

1999 Koguryŏ ŭi kiwŏn kwa Kungnae-sŏng ch’ŏndo 고구려의기원과 국내성 천도 [The origins of Koguryŏ and the removal to Kungnae-sŏng], in Hanbando wa Chungguk tongbuk 3-sŏng ŭi yoksa munhwa 한반도와 중국 동북 3 성의 역사 문화 [The Historical Culture of the Korean Peninsula and the Three Northeastern Provinces of China]: 311-361, ed. Kim Sijun 김시준. Seoul: Sŏul Taehakkyo Ch'ulp'ansa.

SIMA GUANG 司馬光

1992 Zizhi tongjian 資治通鑑 [Comprehensive Mirror for Aid in Government], 20 vols. Beijing: Zhonghua Shuju.

WEI CUNCHENG 魏存成

1994 Gaogouli kaogu 高句丽考古 [Koguryŏ Archaeology]. Changchun: Jilin Daxue Chubanshe.

Yŏ HogYu 余昊奎

2005 Koguryŏ Kungnae ch’ŏndo ŭi sigi wa paegyŏng 高句麗 國內遷都의 시기와 배경 [The date and background of the removal of the Koguryŏ capital to Kungnae]. Han'guk kodaesa yŏn'gu 韓國古代史研究 38(June):37-84.

ZHANG FUYOU 张福有

2004 Ji'an Yushan 3319 hao mu juanyunwen wadang mingwen shidu 集安禹山 3319 号墓卷云纹 瓦当铭纹识读 [Reading of the inscription on curled-cloud end tiles from Tomb 3319 in Ji'an]. Dongbei shidi 东北史地 1:39-44. 